\title{
StreamStats in Georgia: A Water-Resources Web Application
}

Part of the mission of the U.S. Geological Survey (USGS) is to provide information on streamflow in the Nation's streams to help understand the Nation's water resources. Streamflow statistics are used by water managers, engineers, scientists, and others to protect people and property during floods and droughts, and to manage, protect, and enhance water resources. StreamStats is a Web-based Geographic Information System (GIS) application that was created by the USGS, in cooperation with the Environmental Systems Research Institute, Inc., that allows users to easily obtain streamflow statistics, basin characteristics, and descriptive information for USGS streamgages and user-selected ungaged locations on streams (Ries and others, 2008).

StreamStats is being implemented on a State-by-State basis to allow for customization of the data development and underlying datasets to address their specific needs, issues, and objectives. The USGS, in cooperation with the Georgia Environmental Protection Division and Georgia Department of Transportation, has implemented StreamStats for Georgia (fig.1). The Georgia StreamStats Web site is available through the national StreamStats Web-page portal at http://streamstats.usgs.gov. Links are provided on this Web page for individual State applications, instructions for using StreamStats, definitions of basin characteristics and streamflow statistics, and other supporting information.

The current (2014) functionality in the Georgia StreamStats application includes the ability to:

- Navigate and view base-map features in the user interface, such as roads, streams, political boundaries, and USGS topographic maps;

- Zoom in or out to different map scales based on user input of (1) a drawn rectangle surrounding an area of interest,

(2) latitude and longitude coordinates, (3) place name,

(4) stream reach code, or (5) a specified scale;

- Access previously published peak-flow frequency and other streamflow statistics, basin characteristics, and descriptive information for USGS streamgages, plus a link to the USGS National Water Information System that provides access to historical and real-time data collected at selected streamgages;

- Delineate and edit a drainage-basin boundary for a userselected point on a stream (fig. 2);
- Compute basin characteristics, such as drainage area, stream slope, mean annual rainfall, and land cover from the 2006 National Land Cover Dataset, for a user-selected point on a stream (fig. 3);

- Estimate rural and urban peak-flow frequency statistics and provide indicators of the accuracy of the estimates at a userselected point on a stream;

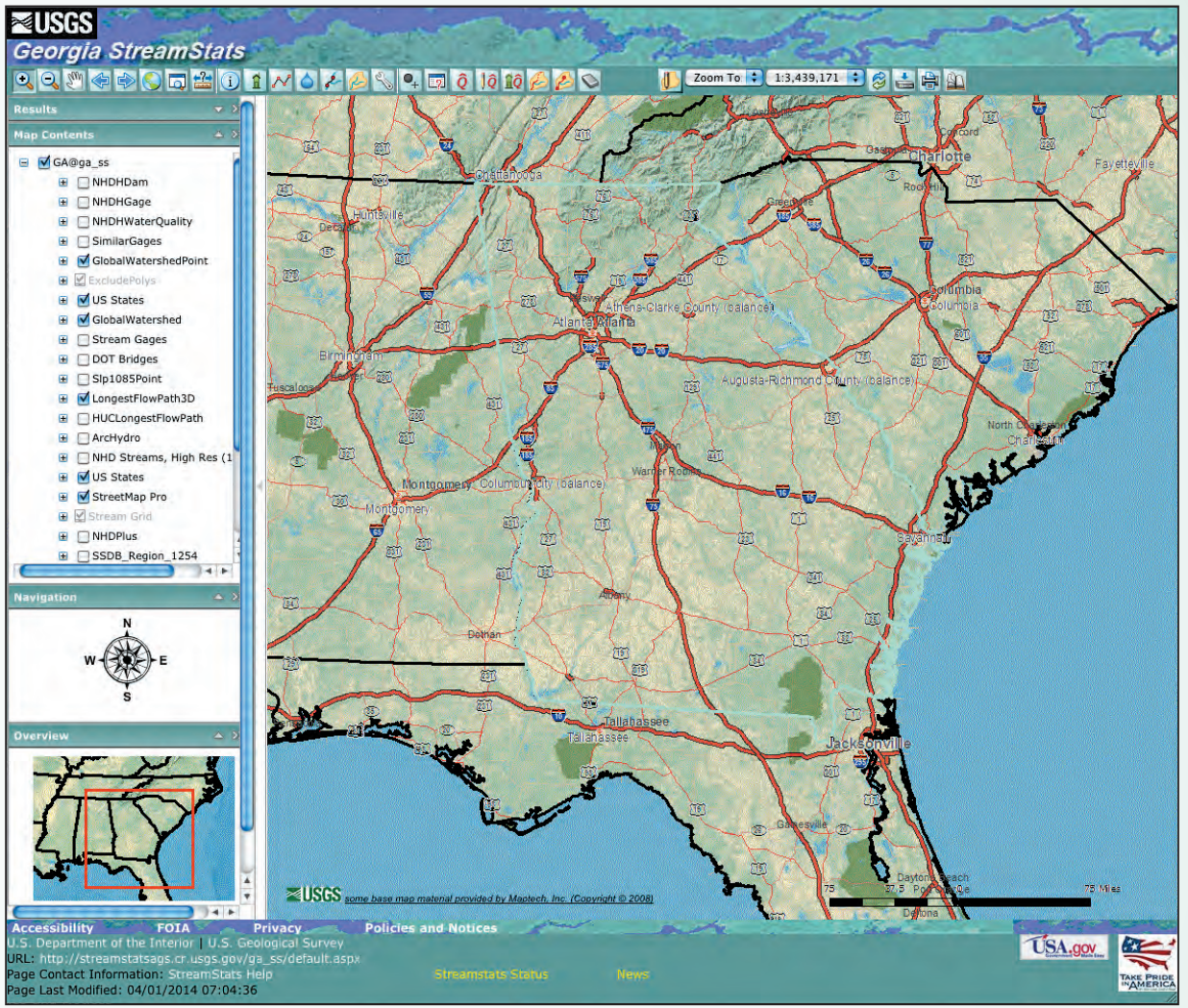

Figure 1. Screen capture of the user interface for the statewide Georgia StreamStats application.
- Download shapefiles of the user-selected basin-outlet point, the delineated basin, the basin's longest flowpath, and the points used to calculate the slope of the longest flowpath for use in other applications, along with associated basin characteristics and streamflow statistics;

- Trace information upstream or downstream from a userselected point on a stream in order to identify the connected stream network and natural or manmade features that may affect the quantity or quality of the streamflow;

- Obtain elevation profiles between selected points on the stream network or the land surface; the profile coordinates ( $x, y$, and $z$ values) can be saved by the user in an Excel format; 


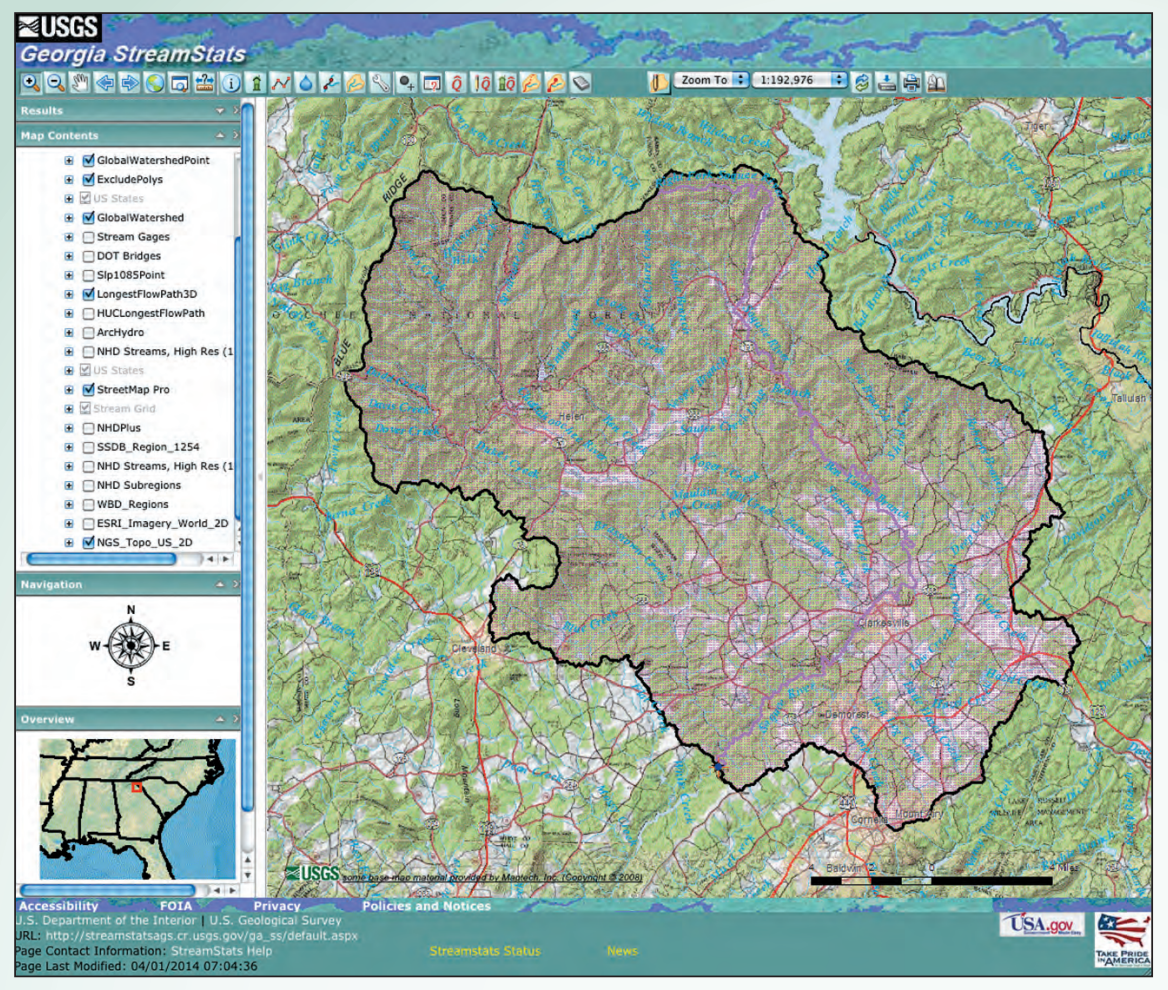

Figure 2. Screen capture of a delineated drainage basin in Georgia StreamStats.

- Trace the flow path of water from a selected point on the land surface to the stream network and then downstream; and

- Print the results displayed in the user-interface map frame, the basin characteristics report, or streamflow statistics in the StreamStats ungaged site report.

Several of these functions may be requested remotely as Web services, which allow other Web sites or desktop GIS applications to access these functions automatically (Ries and others, 2008).

StreamStats can be used to obtain previously published basin characteristics and (or) streamflow statistics for over 700 USGS streamgages in Georgia.

Any regulation to streamflow at the streamgage is noted as well as the type of streamgage, such as continuous or partial record. Currently (2014), 18 basin characteristics are available for a user-selected point on a stream (fig. 3). Streamflow statistics for a user-selected point on a stream are determined through the use of published USGS regional regression equations (Gotvald and others, 2009; Feaster and others, 2014). The user should be familiar with the limitations and accuracy of the regression equations before applying the resulting statistics.

StreamStats automates and provides consistent results for many important computations necessary for the management of water resources in Georgia. Functions, such as automated basin delineation, determination of basin characteristics, and calculation of streamflow statistics at gaged and ungaged locations on a stream, were formerly time intensive and often not reproducible. The Webbased application incorporates important local datasets developed by the State, as well as established national datasets in a framework that allows future updates to be made. Applications as diverse as planning for bridge and road construction, managing water-resources quality and quantity, characterizing drainage basins, or examining the effects of urbanization on streamflow can be implemented with the Georgia StreamStats application.

For more information about this publication, contact: Director, USGS Georgia Water Science Center 1770 Corporate Drive, Suite 500

Norcross, GA 30093

telephone: 678-924-6700

http://ga.water.usgs.gov/

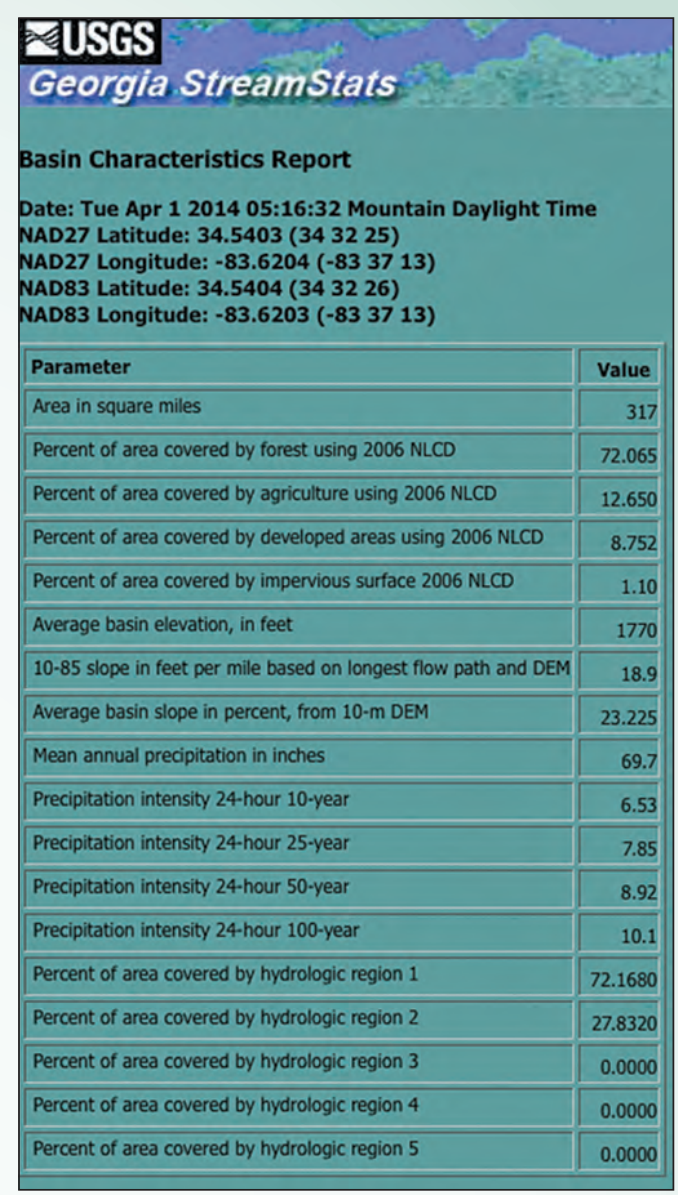

Figure 3. Screen capture of a basin characteristics report for a user-selected point on a stream.

\section{References Cited}

Feaster, T.D., Gotvald, A.J., and Weaver, J.C., 2014, Methods for estimating the magnitude and frequency of floods for urban and small, rural streams in Georgia, South Carolina, and North Carolina, 2011: U.S. Geological Survey Scientific Investigations Report 2014-5030, 104 p., http://dx.doi.org/10.3133/sir20145030.

Gotvald, A.J., Feaster, T.D., and Weaver, J.C., 2009, Magnitude and frequency of rural floods in the southeastern United States, 2006 - Volume 1, Georgia: U.S.

Geological Survey Scientific

Investigations Report 2009-5043, 120 p., http://pubs.usgs.gov/sir/2009/5043/.

Ries, K.G., III, Guthrie, J.G., Rea, A.H., Steeves, P.A., and Stewart, D.W., 2008, StreamStats - A water resources Web application: U.S. Geological Survey Fact Sheet 2008-3067, 6 p., http://pubs.usgs.gov/fs/2008/3067/.

By Anthony J. Gotvald and Jonathan W. Musser 